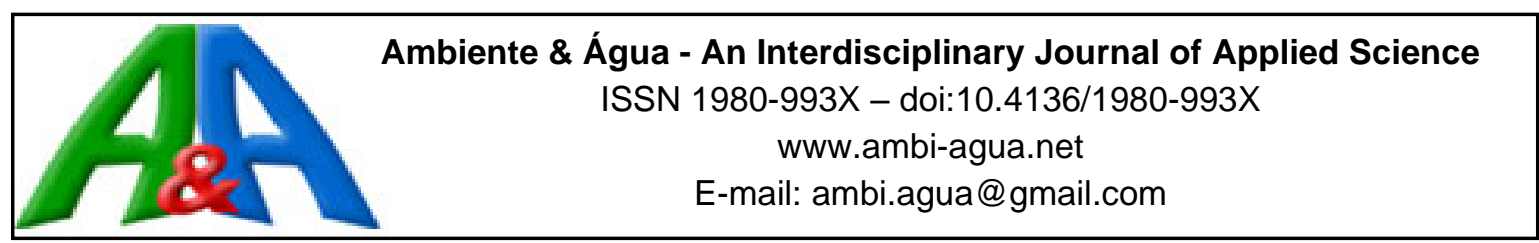

\title{
Potential mutagenic effects of the glyphosate herbicide on Gymnotus inaequilabiatus (Valenciennes, 1839)
}

ARTICLES doi:10.4136/ambi-agua.2730

Received: 30 Mar. 2021; Accepted: 16 Jul. 2021

\author{
Larissa Nayara Lima Silva*iD; Claumir Cesar Muniz ${ }^{D}$; \\ Ernandes Oliveira Sobreira Junior ${ }^{D}$; Áurea Regina Alves Ignácio
}

\begin{abstract}
Centro de Pesquisa de Limnologia, Biodiversidade, Etnobiologia do Pantanal. Programa de Pós-graduação em Ciências Ambientais. Universidade do Estado de Mato Grosso (UEM), Cidade Universitária (Bloco II), Avenida Santos Dumont, s/n, CEP: 78200-000, Cáceres, MT, Brazil. E-mail: claumir@unemat.br, ernandes.sobreira@gmail.com, aurea@unemat.br *Corresponding author. E-mail: larissa.lima1507@gmail.com
\end{abstract}

\begin{abstract}
This study analyzed the occurrence of nuclear damage in the red blood cells of Gymnotus inaequilabiatus (Valenciennes, 1839), exposed in vivo to the herbicide glyphosate. The fish were distributed in four groups, namely: control (without addition of herbicide) and contaminated groups with application of $65 \mu \mathrm{g} / \mathrm{L}$ (concentration allowed by CONAMA Resolution), $1 \mathrm{mg} / \mathrm{L}$ (maximum limit recommended by the World Health Organization - WHO and Food and Agriculture Organization - FAO) and $5 \mathrm{mg} / \mathrm{L}$ (overdose, five times higher than that by WHO and FAO). For the analysis of cell damage, the method of Nuclear Erythrocytic Abnormalities (NEA) was used, containing 1000 cells for duplicate elimination. An increase in cell damage was observed for 144 hours (6-days) of exposure in all controls. Even under a small concentration, there was a clear effect on segmented, renal, lobed formation and mainly on the formation of micronuclei. The high damage was caused in the first 48 hours and reduced after 144 hours, where the fish can have the herbicidal effect blocked. Studies that analyze the mechanisms of action of glyphosate-based herbicides are essential to determine the risks caused by biota, since there is a great divergence on the maximum tolerable limits in water, which affect quality and integrity of these ecosystems.
\end{abstract}

Keywords: cell damage, fish, Roundup®.

\section{Potenciais efeitos mutagênicos do herbicida glifosato em Gymnotus inaequilabiatus (Valenciennes, 1839)}

\section{RESUMO}

O objetivo desse estudo foi analisar a ocorrência de danos nucleares nas hemácias de Gymnotus inaequilabiatus, expostos in vivo ao herbicida glifosato. Os peixes foram distribuídos em quatro grupos, sendo eles: controle (sem a adição do herbicida) e os grupos contaminados nas concentrações de $65 \mu \mathrm{g} / \mathrm{L}$ (concentração permitida pela Resolução do CONAMA), $1 \mathrm{mg} / \mathrm{L}$ (limite máximo recomendado pela Organização Mundial de Saúde - OMS e Food and Agriculture Organization - FAO) e de $5 \mathrm{mg} / \mathrm{L}$ (superdose, cinco vezes maior que a estabelecida pela OMS e FAO). Para análise de danos celulares foi utilizado o método de Anormalidades Nucleares Eritrocíticas (ANE) contando 1000 células por lâmina em duplicatas. Foi observado 
um aumento nos danos celulares durante as 144 horas de exposição (6 dias) em todos os tratamentos. Mesmo sob uma pequena concentração, houve um claro efeito sobre a formação segmentada, renal, lobada e principalmente na formação de micronúcleos. Os elevados danos foram causados nas primeiras 48 horas sendo reduzidos após 144 horas, onde o peixe pode ter bloqueado o efeito do herbicida. Estudos que analisam os mecanismos de ação de herbicidas à base de glifosato, são fundamentais para a determinação dos riscos causados à biota, já que há grande divergência sobre os limites máximos toleráveis na água, podendo causar impactos na qualidade e integridade desses ecossistemas.

Palavras-chave: dano celular, peixe, Roundup ${ }^{\circledR}$.

\section{INTRODUCTION}

Glyphosate is an organophosphate compound absorbed by the chlorophyll region of plants belonging to the group of "glycine", its molecule is not perceived as a potential aggressor and may inhibit the synthesis of essential amino acids present only in plants (Galli and Montezuma, 2005). For this reason, this compound can be considered as of lower risk for humans and wild fauna since it basically acts on physiological reactions existing only in plants (Galli and Montezuma, 2005; Mesnage et al., 2015).

However, its commercial formulation is composed of $41 \%$ glyphosate in the form of isopropylamine salt (Modesto and Martinez, 2010) and 59\% inert ingredients. The inert ingredients act as solvents, preservatives or surfactants such as polyoxymethylene (POEA), whose function is to increase the contact of the product with the leaf to aid its adhesion (Folmar et al., 1979). More than the effect of pure glyphosate, aggregates are reported to be 20 to 70 times more toxic to fish and aquatic invertebrates (Modesto and Martinez, 2010).

In the aquatic environment (the main receptor for these substances), the deposition of these contaminants can have short (acute), medium (sub chronic) and long-term (chronic) consequences, which may compromise behavior, growth, development, tissue structure, reproduction or even cause mass lethality in aquatic populations (Rand and Petrocelli, 1985; Bogoni et al., 2014; Mesnage et al., 2015).

In fish, for example, there is an accumulation of high concentrations of this pollutant, because they can accumulate higher concentrations of these substances present in the water, since these compounds can bind to the organic matter that is ingested by them (Nimmo, 1985).

Due to their relative sensitivity to changes in the environment, fish are frequently used in studies of toxicity of pesticides, and biochemical, physiological and histological changes can be observed (Glusczak et al., 2011; Harayashiki et al., 2013, Armiliato et al., 2014; Fiorino et $a l ., 2018)$. In these non-target organisms, the stress caused by the accumulation of these contaminants promotes the development of cellular abnormalities or may even cause chromosome breakdown in the DNA molecules (Al-Sabti and Metcalfe, 1995), making the pollutant a potential genotoxic mechanism (Lushchak et al., 2009).

Even if glyphosate is reported to have a lifespan of up to 15 days (Galli and Montezuma, 2005), it is believed that the time of continuous exposure to this substance can increase damage to cell nuclei. This study therefore analyzed the nuclear damage in the red blood cells of Gymnotus inaequilabiatus (Valenciennes, 1839) exposed to the herbicide glyphosate. To conduct this research, we hypothesized that: 1) Fish exposure to the herbicide will cause damage to the nuclear cells of the fish, mainly after the first 48 hours; 2) Damage to the blood cells will appear even under low concentrations of the herbicide. 


\section{MATERIAL AND METHODS}

\subsection{Fish breeding and maintenance}

For the development of this experiment, the species adults $G$. inaequilabiatus ( $\mathrm{n}=80 ; 16.5$ $\mathrm{cm}$ to $26.4 \mathrm{~cm}$ ) was obtained in stores selling fish products. This species was chosen due to its frequent use as live bait in the Pantanal and for also being easy to maintain in confined environments for in vivo experimentation.

The individuals were transported to the Ecotoxicology Laboratory, linked to the Limnology, Biodiversity and Ethnobiology Research Center of the Pantanal (Celbe) of the University of the State of Mato Grosso on the university campus of Cáceres.

In the laboratory, in order to reduce stress and the proliferation of fungi and bacteria, the fish underwent an acclimatization period of four hours contained in four 200-liter polyethylene reservoirs. Soon after, the individuals were bathed in a solution of potassium permanganate (1 gram/20 liters of water).

The individuals were not fed during the entire experiment so that there was no interference with the treatments. It is important to note that there was no significant decrease between the average weights (grams) of the individuals between the beginning and the end of the experiment. Individuals varied between $16.5 \mathrm{~cm}$ to $26.4 \mathrm{~cm}$ in length, and their weight varied between 17.63 and 52.46 grams.

The study was approved by the Animal Use Ethics Committee of the State University of Mato Grosso - MT, under Opinion Number: 003/2019.

\subsection{Experimental design and data collection}

The fish were distributed in four mesocosms of 200 liters, setting a density of 1 fish for every 4 liters of water. Each mesocosm was supplied with dechlorinated water. The parameters analyzed in the water were: temperature $\left({ }^{\circ} \mathrm{C}\right)$, dissolved oxygen $(\mathrm{mg} / \mathrm{L})$, electrical conductivity $(\mu \mathrm{S} / \mathrm{cm})$, and $\mathrm{pH}$. These parameters were monitored daily with the aid of a multiparametric probe (Horiba U-55).

Each mesocosm represented a treatment with different concentrations of the herbicide Roundup® (Monsanto do Brazil Ltda). The following concentrations were used: 1) control treatment without any concentration of the herbicide; 2) $65 \mu \mathrm{g} / \mathrm{L}$ (maximum concentration allowed in freshwater, determined by CONAMA Resolution No. 357/2005); 3) $1 \mathrm{mg} / \mathrm{L}$ (maximum concentration recommended in waters by the World Health Organization - WHO and Food and Agriculture Organization - FAO); and 4) $5 \mathrm{mg} / \mathrm{L}$ (overdose, five times greater than that recommended by WHO and FAO) (Araujo et al., 2016).

For fish analysis, 5 specimens and 33.33 liters of water were removed from each aquarium (to maintain the same density in the different treatments) in the periods of $48 \mathrm{~h}, 96 \mathrm{~h}, 144 \mathrm{~h}$ and $192 \mathrm{~h}$, corresponding to the 8 days on display.

The fish were anesthetized with benzocaine (100 mg/L) (Albinati et al., 2007), biometric measurements (total length and total weight) were measured, and blood samples were collected from the gills with heparinized syringes to avoid blood clotting.

\subsection{NEA methodology (nuclear erythrocytic abnormalities) and micronucleus test}

To determine nuclear anomalies, the method of Al-Sabti and Metcalfe (1995) was used by means of blood smears, stained with the Rosenfeld solution for 15 minutes, then adding the same amount of distilled water for another 10 minutes.

1000 cells per slide were counted in duplicates, with the aid of an optical microscope, analyzing the cells (Figure 1) with normal nuclei and the following anomalies: formation of micronuclei, kidney-shaped nuclei, lobed nuclei and segmented nuclei. The frequency of damage was considered as the sum of the damages, disregarding the number of normal cells. 


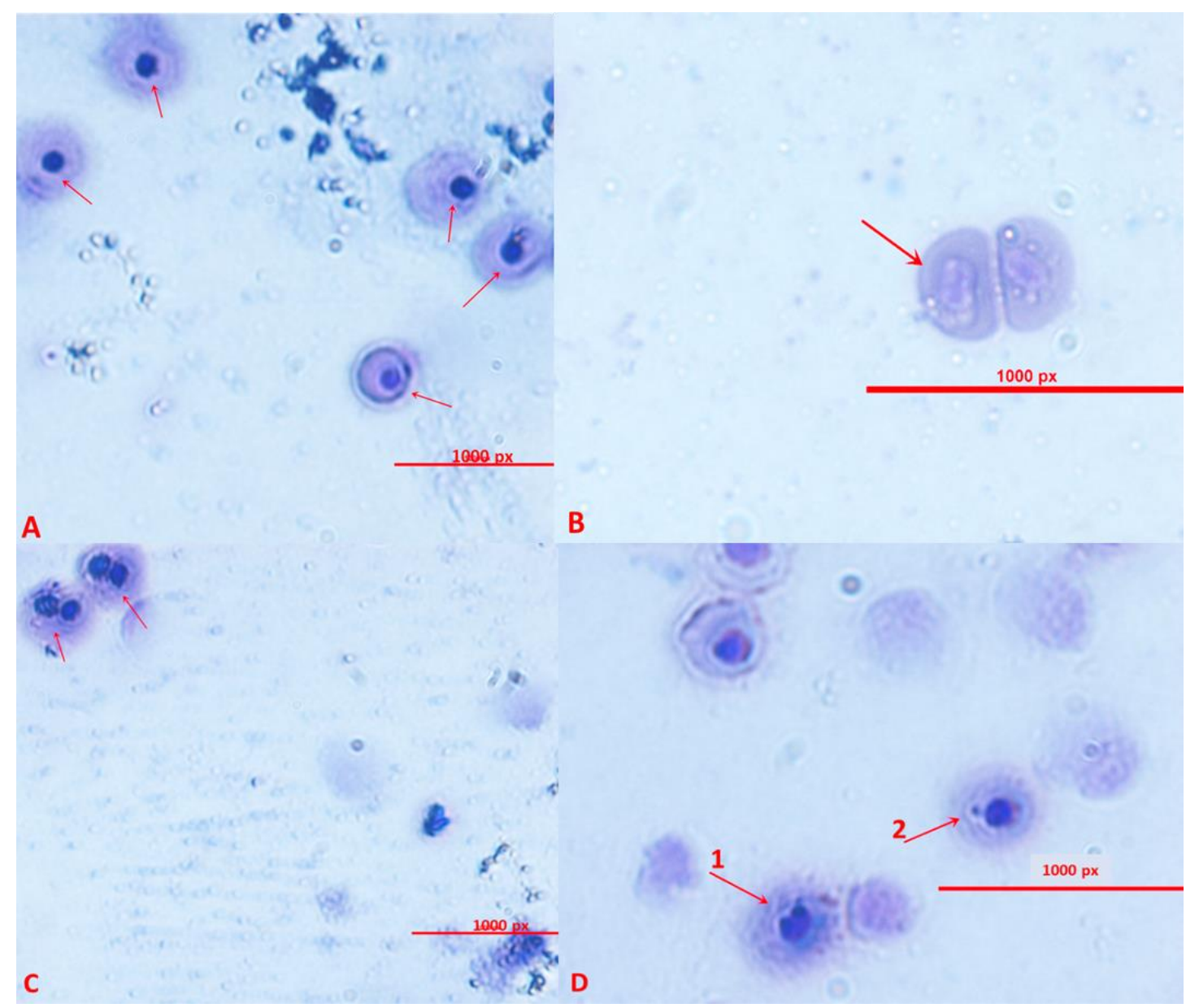

Figure 1. Erythrocytes analyzed using the NEA method and micronucleus test (px1000). Figure A. Normal cells. Figure B. Cell showing lobed nucleus. Figure C. Cells showing segmented nuclei. Figure D1. Kidney-shaped cells. Figure D2. Cell containing micronucleus. Source: author.

\subsection{Statistical analysis}

The Kruskal-Wallis Test and Dunn's a posteriori method (1964) was used for the analysis between treatments according to the time of exposure and nuclear damage in the red blood cells (NEA).

\section{RESULTS AND DISCUSSION}

When comparing treatments according to the time of acute exposure with glyphosate herbicide (Figure 2), we can see that immediately after the exposure of fish to concentrations of $1 \mathrm{mg} / \mathrm{L}$ and $5 \mathrm{mg} / \mathrm{L}$ with the highest total nuclear damage were found: $\chi^{2}(2.3)=17.58, \mathrm{p}=$ 0.000536 for 48 hours; $\chi^{2}(2.3)=17.58, \mathrm{p}=0.0005362$ for 96 hours and $\chi^{2}(2.3)=14.31, \mathrm{p}=$ 0.002512 for 144 hours; $\mathrm{p}<0.05$ for all comparisons. After 192 hours of exposure, only the treatment with a concentration of $5 \mathrm{mg} / \mathrm{l}$ showed higher total cell damage $\left(\chi^{2}(2.3)=12.26, \mathrm{p}=\right.$ 0.006538 ) for 192 hours.

According to these results, all concentrations tested in this study caused the formation of some erythrocytic nuclear anomaly compared to the control, even at the lower concentration, which is the one allowed by the Brazilian resolution (CONAMA) and suggested by WHO and FAO. The mutagenic effects caused by exposure to the herbicide glyphosate can affect the interpretation and transmission of genetic information, which can cause the observed anomalies (Srinivas et al., 2019). 


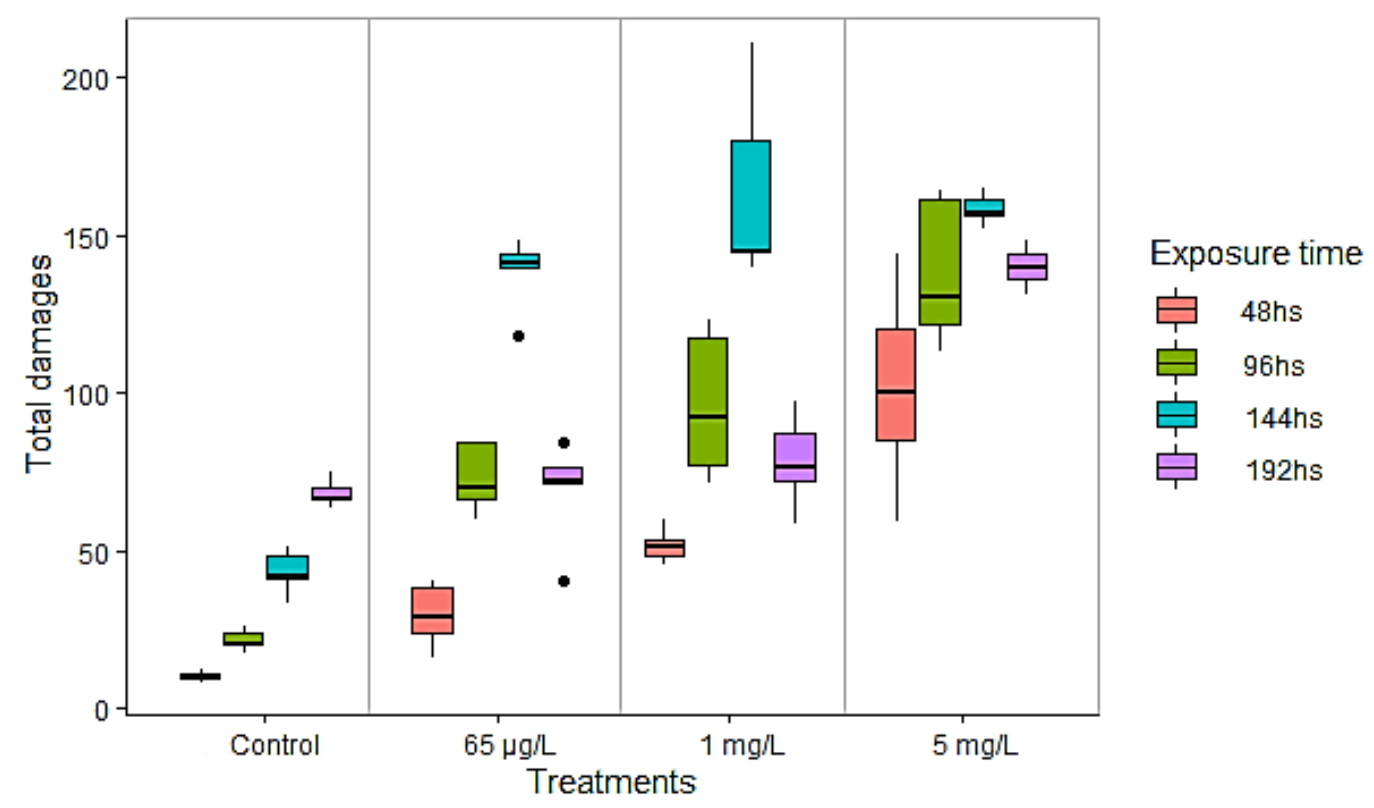

Figure 2. Boxplot showing the total cell damage within the different treatments (control and mesocosms contaminated with the glyphosate herbicide) and the time of exposure. Lines within boxes denote median fluxes. Boxes represent the $25^{\text {th }}$ and $75^{\text {th }}$ percentiles. Whiskers represent variability outside the upper and lower quartiles. Dots represent values outside of the range of the whiskers, but not outliers.

The oxidative stress caused by glyphosate through the accumulation of acetylcholine in the synaptic clefts generates free radicals and changes in the antioxidant system. Among the consequences caused by the primary deleterious effects of oxidative stress is the damage to the ADN molecules in which these changes occur, the potential genotoxicity mechanism (Wang et al., 1998; Watt et al., 2007; Lushchak et al., 2009).

The occurrence of micronuclei showed that there was no significant difference in damage between the periods of exposure (192 hours) (Kruskal-Wallis test; $\chi^{2}(2.3)=1.49, p=0.68$ (Figure 3)).

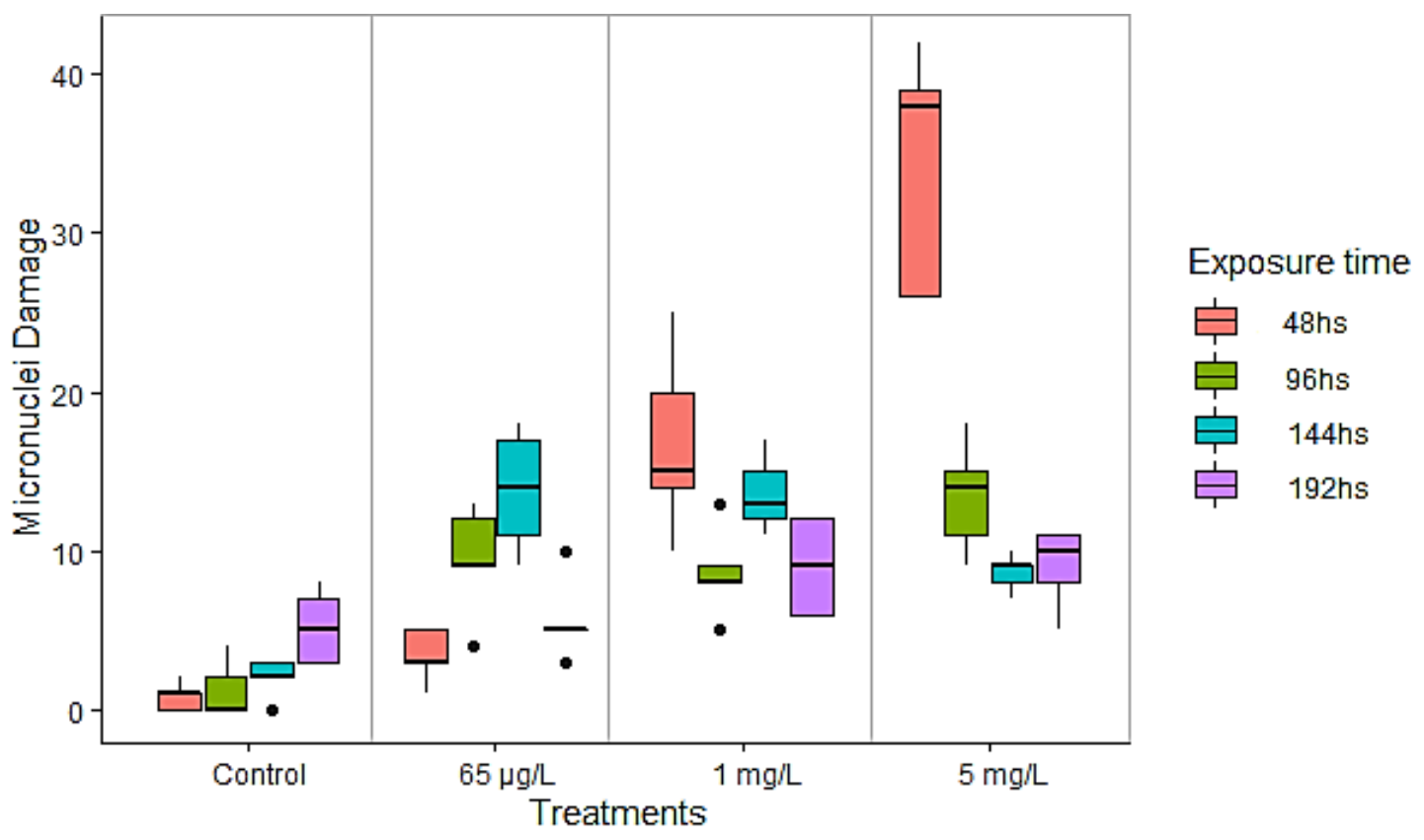

Figure 3. Analysis between the different treatments (control and mesocosms contaminated with the glyphosate herbicide) and cell damage with micronuclei formation. 
However, there was a significant increase between contaminated treatments compared to the control in the formation of nuclei with lobed damage and kidney shape $\left(\chi^{2}(2.3)=28.07, \mathrm{p}\right.$ $<0.001$ and $\chi^{2}(2.3)=30.10, \mathrm{p}<0.001$, respectively) (Figures 4 and 5, respectively); and, in the occurrence of segmented nuclear damage $\left(\chi^{2}(2.3)=10.62, p=0.01\right)$ (Figure 6).

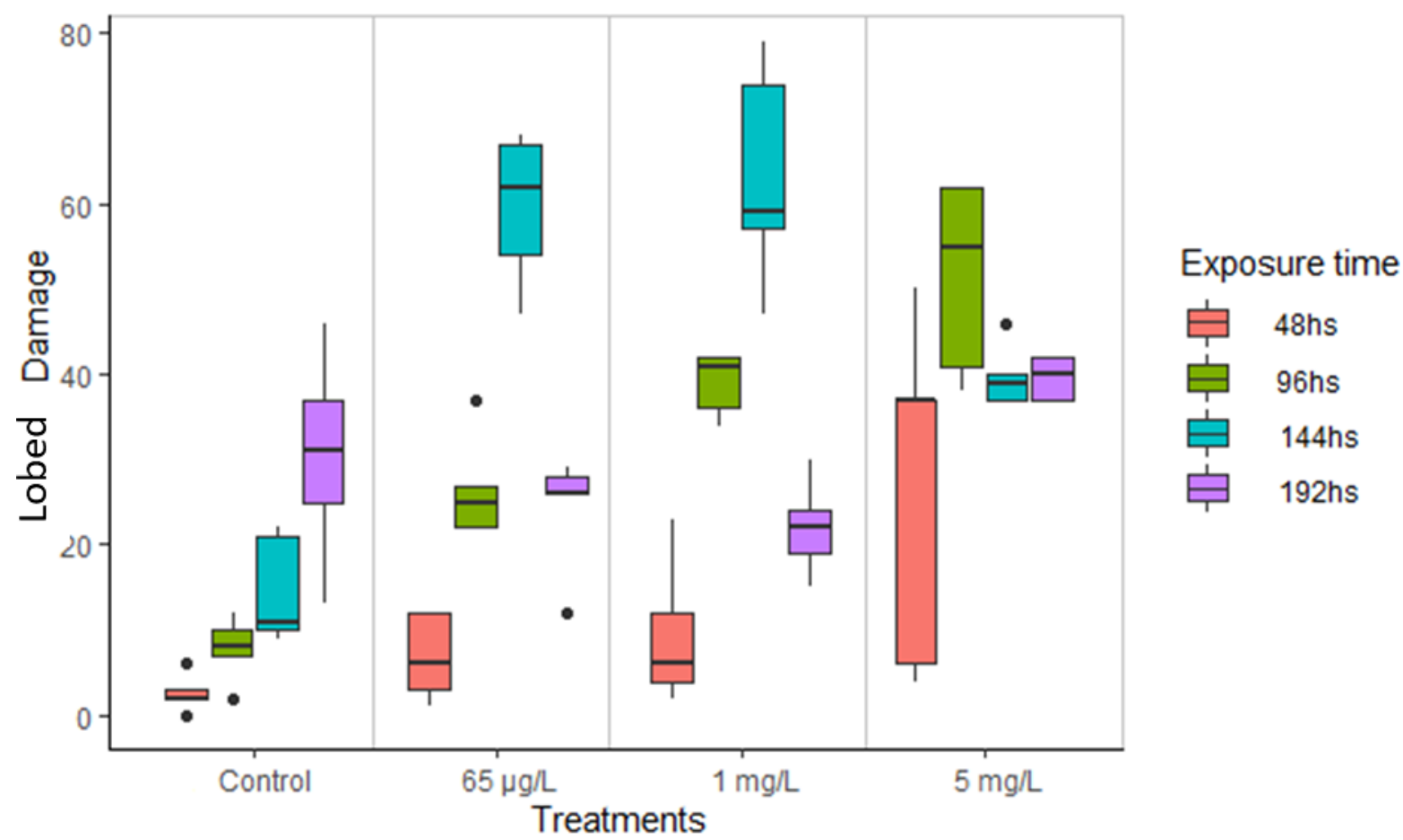

Figure 4. Analysis between the different treatments (control and mesocosms contaminated with the glyphosate herbicide) and cell damage with lobed nuclei formation.

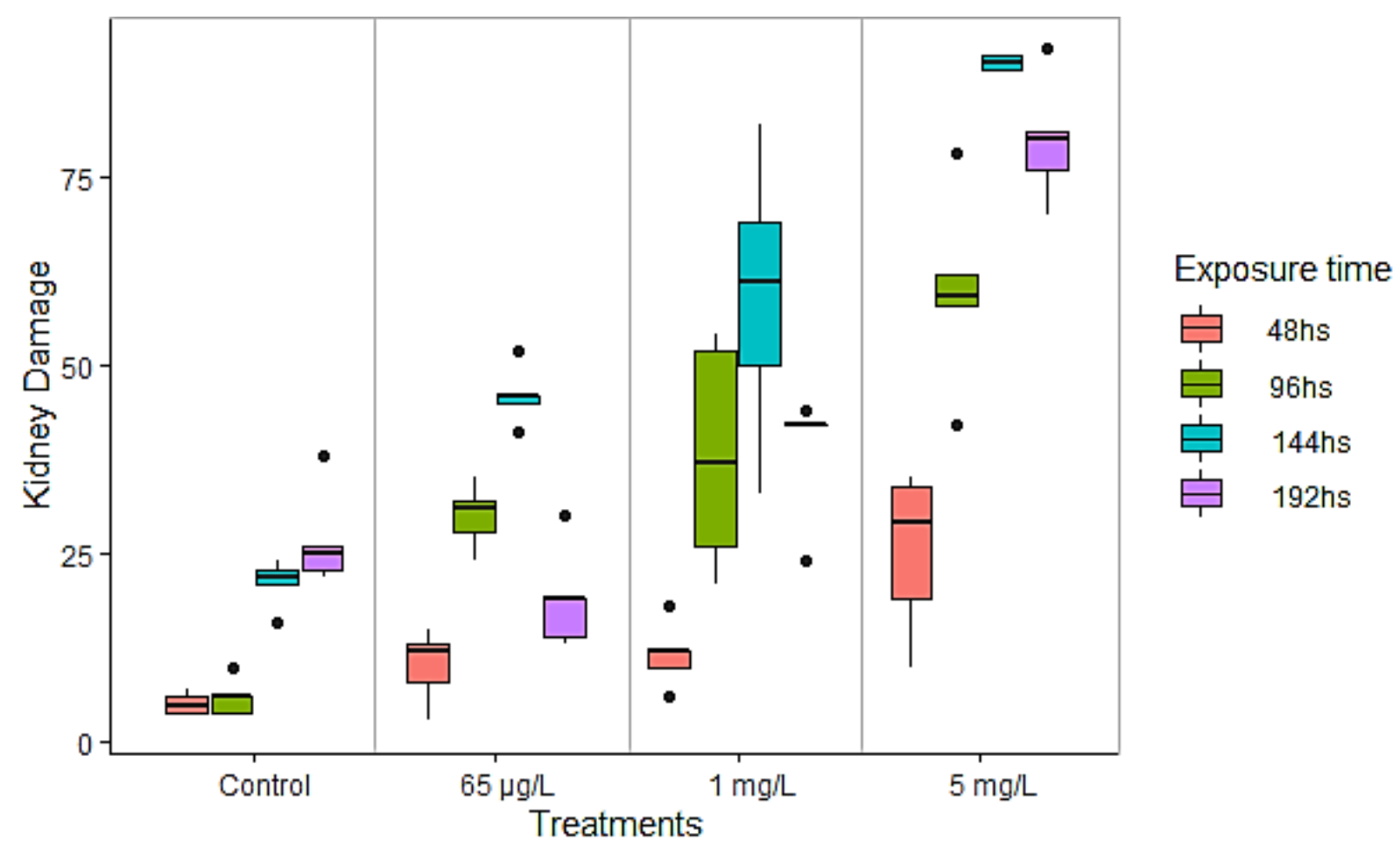

Figure 5. Analysis between the different treatments (control and mesocosms contaminated with the glyphosate herbicide) and cell damage with kidney-shaped nuclei formation. 


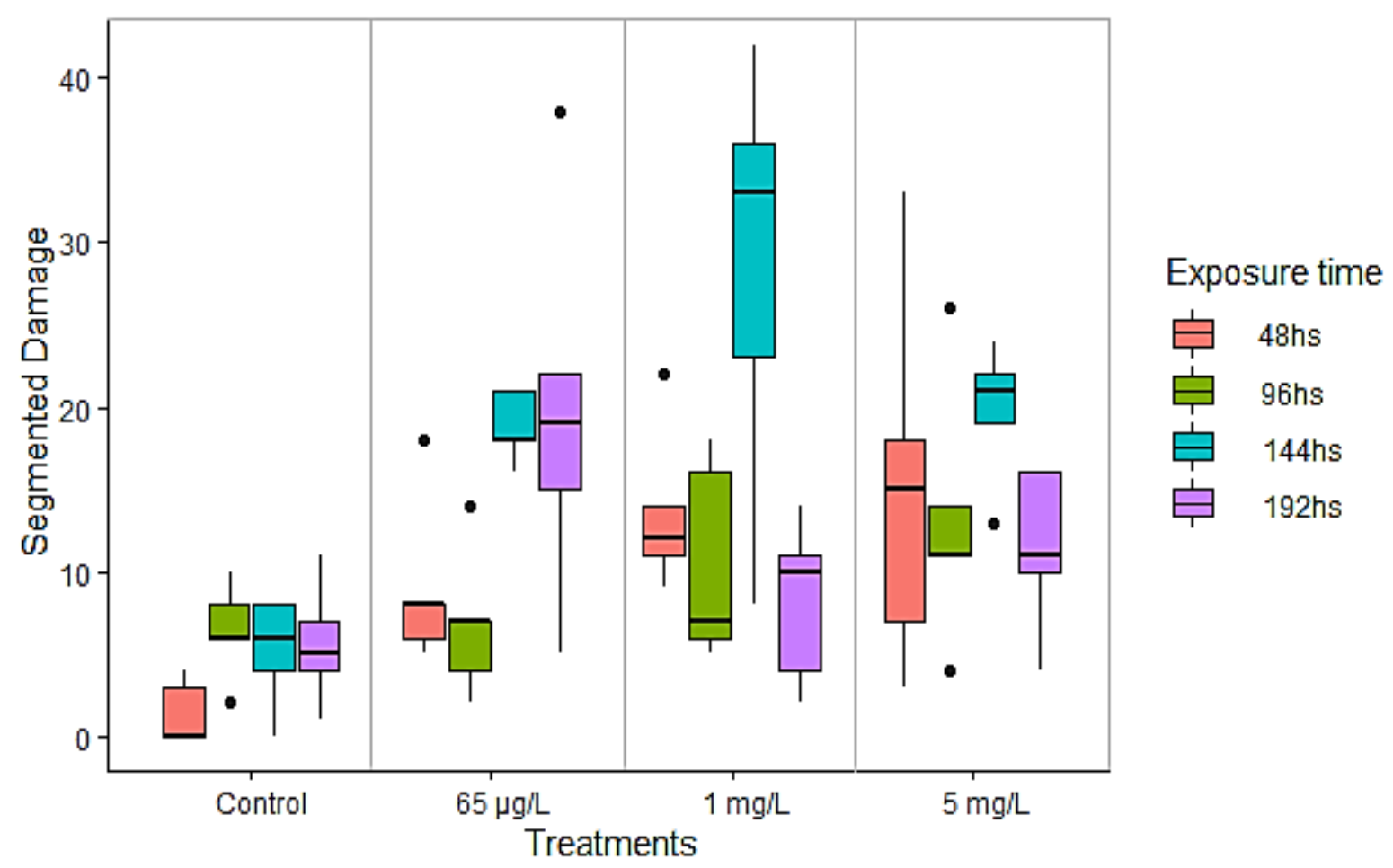

Figure 6. Analysis between the different treatments (control and mesocosms contaminated with the glyphosate herbicide) and cell damage with segmented nuclei formation.

The formation of micronuclei is the result of chromosome fragmentation, which during the cell division process (anaphase), does not migrate to the cell poles, and can also be formed by apoptosis or inactivation of the spindle formation due to chemical or physical agents (Al-Sabti and Metcalfe, 1995).

The ability of several glyphosate-based products to induce increased micronucleus formation has been found in other studies (Bolognesi et al., 1997; Clements et al., 1997; Williams et al., 2000; Cavas, 2011; Cavalcante et al., 2008; Mañas et al., 2009; Poletta et al., 2011). In the present study, there was no significant increase in micronucleus formation in the observed treatments. According to Bonifacio and Hued (2019), the non-significant increase in micronuclei can be explained by the fact that concentrations and exposure periods differ.

Formations of cells with lobed nuclei (Figure 4), on the other hand, may be associated with an attempt to increase the oxygen transport capacity in waters contaminated with chemical substances, when a direct cell division called "amitosis" occurs, also generating bilobed or even anucleate nuclei (Barni et al., 1995). In our study, for all the treatments including the control, after 48 and 96 hours there was an increase in lobed cells. After 144 hours the damages increased only for the $65 \mu \mathrm{g} / \mathrm{L}$ and $1 \mathrm{mg} / \mathrm{L}$, but not in the $5 \mathrm{mg} / \mathrm{L}$. A similar pattern was observed for the kidney-shaped nuclei formation (Figure 5).

The morphological changes of the nuclei can be induced through the influence of cytotoxic compounds on the integrity of the nuclear lamina responsible for the stability and the regular oval shape of the nucleus (Alberts et al., 2002). However, another possible explanation would be the possibility due to the body's attempt to eliminate genetic damage in situations of stress or exposure to chemical contaminants, in which when detecting the genetic damage, the process of recovery or elimination of excess chromatin begins to be moved to outside the nucleus and eliminated by exocytosis presenting imperfections before being completed (Carrasco et al., 1990; Fenech et al., 2011).

This process of eliminating damage by exocytosis may be a possible explanation for the reduction of damage formation between the exposure periods of 144 and 192 hours only for the concentration of overdose, with a temporary blockage by the organism to the poisoning. 
We also accept that in the control treatments there were similar patterns of damages, where the total damages showed a linear increase, for instance (Figure 2). However, the contaminated treatments presented $768,11 \%$ times more damage than the control.

Greater survival of specimens at higher doses was observed, corroborating other research with pesticides (Storrs and Kiesecker, 2004; McMahon et al., 2013). The occurrence of these results in a non-linear way between concentrations and mortality can be related to chemicals with endocrine-disrupting action. Even if these animals survive in high concentrations of contaminants, this period of exposure can cause other negative consequences, some irreversible (Relyea, 2005; Beausoleil et al., 2013; Lagarde et al., 2015).

According to Turek et al. (2018) more and more studies show that concentrations even below the limits allowed by legislation are harmful to organisms as prolonged exposure, and in this context studies like the present reinforce the need to analyze non-lethal concentrations of pesticides, whose silent effects can affect organisms on several levels.

However, the values determined as maximum limits allowed in freshwater established by Brazilian Government Resolution (CONAMA resolution n.357/2005) were defined for the active principle, disregarding the complex formulation sold commercially with surfactants, solvents and preservatives which, when associated with glyphosate, makes it more toxic (Kier and Kirkland, 2013; De Castilhos Ghisi et al., 2016).

In fact, scientific studies demonstrate that glyphosate acts causing hepatic, renal and reproductive toxicity, neurotoxicity, teratogenicity, tumorigenicity, carcinogenicity and endocrine disruption (Antoniou et al., 2012; Cattani et al., 2014; Greim et al., 2015); Mesnage et al., 2015; Kegley et al., 2016; Mesnage et al., 2017), which caused the World Health Organization's in 2017 to alert the world about its use and effect (Cook, 2019).

\section{CONCLUSION}

It has been observed that the formation of cell damage increases with the period of exposure to glyphosate. We have hereby shown that the initial exposure of glyphosate increased blood-cell damage in 768 , or $11 \%$, of the exposed fish. This once more shows the effects of this herbicide used worldwide. This accretion of blood cells damage is seen for 144 hours (6-days), during which the organisms may have adapted to (blocked) the contaminant. Considering the Brazilian Government Resolution and the world organizations, we argue that even the lower concentration of the herbicide in the water causes an effect on the blood cells of fish and must be recognized as a toxic substance for the water.

Studies recognizing the mechanism of action of the herbicide, mainly for the characterization of its acute, sub chronic and chronic effects, are essential for the risk assessment of the use of these contaminants. There is a considerable divergence regarding the consensus for the maximum acceptable limits of glyphosate in the water, but even the lower concentration changes the quality and integrity of ecosystems at risk.

\section{ACKNOWLEDGEMENTS}

To the biodiversity erosion project in the Upper Paraguay basin: impacts of land use on the structure of vegetation and the community of terrestrial and aquatic vertebrates. Public notice of research networks in Mato Grosso No. 037/2016 / FAPEMAT.

\section{REFERENCES}

ALBERTS, B.; BRAY, D.; LEWIS, J.; RAFF, M.; ROBERTS, K.; WALTER, P. Biologia Molecular da Célula. Porto Alegre: Artmed, 2002.

Rev. Ambient. Água vol. 16 n. 5, e2730 - Taubaté 2021 
ALBINATI, A. C. L.; MOREIRA, E. L. T.; ALBINATI, R. C. B.; CARVALHO, J. V. D.; SANTOS, G. B.; LIRA, A. D. D. Toxicidade aguda do herbicida Roundup® para Piauçu ("Leporinus macrocephalus"). Revista Brasileira de Saúde e Produção Animal, v. 8, n. 3, p. 184-192, 2007.

AL-SABTI, K.; METCALFE, C. D. Fish micronuclei for assessing genotoxicity in water. Mutation Research/Genetic Toxicology, v. 343, n. 2-3, p. 121-135, 1995. https://doi.org/10.1016/0165-1218(95)90078-0

ANTONIOU, M.; HABIB, M.; HOWARD, C. V.; JENNINGS, R. C.; LEIFERT, C.; NODARI, R. O. et al. Teratogenic effects of glyphosate-based herbicides: divergence of regulatory decisions from scientific evidence. Environmental \& Analytical Toxicology, v. 4, n. 6, p. 2161-0525, 2012. http://dx.doi.org/10.4172/2161-0525.S4-006

ARAUJO, J. S. A.; DELGADO, I. F.; PAUMGARTTEN, F. J. R. Glyphosate and adverse pregnancy outcomes, a systematic review of observational studies. BMC Public Health, v. 16, n.1, p. 472, 2016. https://doi.org/10.1186/s12889-016-3153-3 .

ARMILIATO, N.; AMMAR, D.; NEZZI, L.; STRALIOTTO, M.; MULLER, Y. M.; NAZARI, E. M. Changes in ultrastructure and expression of steroidogenic factor-1 in ovaries of zebrafish Danio rerio exposed to glyphosate. Journal of Toxicology and Environmental Health, Part A, v. 77, n. 7, p. 405-414, 2014. https://doi.org/10.1080/15287394.2014.880393

BARNI, S.; FRASCHINI, A.; PROSPERI, E.; VACCARONEL, R.; BERNINI, F. Possible occurrence of amitotic cell division during hematopoiesis in the Urodeles. Comparative $\begin{array}{llllllll}\text { Haematology International, } & \text { v. } 5, \quad \text { n. } 3, \quad \text { p. 183-188, }\end{array}$ https://doi.org/10.1007/BF00368042

BEAUSOLEIL, C.; ORMSBY, J. N.; GIESA, H. U.; HEINDEL, J. J.; HOLMER, M. L.; NIELSEN, P. J. et al. Low dose effects and non-monotonic dose responses for endocrine active chemicals: science to practice workshop: workshop summary. Chemosphere, v. 93, n. 6, p. 847-856, 2013. https://doi.org/10.1007/s00244-013-9990-5

BOGONI, J. A.; ARMILIATO, N.; ARALDI-FAVASSA, C. T.; TECHIO, V. H. Genotoxicity in Astyanax bimaculatus (Twospot Astyanax) Exposed to the Waters of Engano River (Brazil) as Determined by Micronucleus Tests in Erythrocytes. Arch Environ Contam Toxicol, v. 66, n. 3, p. 441-449, 2014. https://doi.org/10.1007/s00244-013-9990-5.

BOLOGNESI, C.; BONATTI, S.; DEGAN, P.; GALLERANI, E.; PELUSO, M.; RABBONI, R. et al. Genotoxic activity of glyphosate and its technical formulation Roundup. Journal of Agricultural and food chemistry, v. 45, n. 5, p. 1957-1962, 1997. https://doi.org/10.1021/jf9606518

BONIFACIO, A. F.; HUED, A. C. Single and joint effects of chronic exposure to chlorpyrifos and glyphosate based pesticides on structural biomarkers in Cnesterodon decemmaculatus. $\begin{array}{lllll}\text { Chemosphere, } & \text { v. } & 236, & \text { p. } & 124311,\end{array}$ https://doi.org/10.1016/j.chemosphere.2019.07.042

CARRASCO, K. R.; TILBURY, K. L.; MYERS, M. S. Assessment of the piscine micronucleus test as an in situ biological indicator of chemical contaminant effects. Canadian Journal of Fisheries and Aquatic Sciences, v. 47, n. 11, p. 2123-2136, 1990. https://doi.org/10.1139/f90-237 
CATTANI, D.; CAVALLI, V. L.; RIEG, C. E.; DOMINGUES, J. T.; DAL-CIM, T.; TASCA, C. I.; SILVA, F. R.; ZAMONER, A. Mechanisms underlying the neurotoxicity induced by glyphosate-based herbicide in immature rat hippocampus: involvement of glutamate $\begin{array}{llllllll}\text { excitotoxicity. Toxicology, v. } 5, \quad \text { n. } 320, & \text { p. } 34-45,\end{array}$ https://doi.org/10.1016/j.tox.2014.03.001

CAVAlCANTE, D. G. S. M.; MARTINEZ, C. B. R.; SOFIA, S. H. Genotoxic effects of Roundup ${ }^{\circledR}$ on the fish Prochilodus lineatus. Mutation Research/Genetic Toxicology and Environmental Mutagenesis, v. 655, n. 1-2, p. 41-46, 2008. https://doi.org/10.1016/j.mrgentox.2008.06.010

CAVAS, T. In vivo genotoxicity evaluation of atrazine and atrazine-based herbicide on fish Carassius auratus using the micronucleus test and the comet assay. Food and Chemical Toxicology, v. 49, n. 6, p. 1431-1435, 2011. https://doi.org/10.1016/j.fct.2011.03.038

CLEMENTS, C.; RALPH, S.; PETRAS, M. Genotoxicity of select herbicides in Rana catesbeiana tadpoles using the alkaline single-cell gel DNA electrophoresis (comet) assay. Environmental and Molecular Mutagenesis, v. 29, n. 3, p. 277-288, 1997. https://doi.org/10.1002/(SICI)1098-2280(1997)29:3\%3C277::AID-EM8\%3E3.0.CO;2-9

COOK, K. Glyphosate Pesticide in Beer and Wine. Washington, DC: FUND, US PIRG Education, 2019.

DE CASTILHOS GHISI, N.; OLIVEIRA, E. C.; PRIOLI, A. J. Does exposure to glyphosate lead to an increase in the micronuclei frequency? A systematic and meta-analytic review. Chemosphere, v. 145, 42-54, 2016. https://doi.org/10.1016/j.chemosphere.2015.11.044

FENECH, M.; KIRSCH-VOLDERS, M.; NATARAJAN, A. T.; SURRALLES, J.; CROTT, J. W., PARRY, J. et al. Molecular mechanisms of micronucleus, nucleoplasmic bridge and nuclear bud formation in mammalian and human cells. Mutagenesis, v. 6, n. 1, p. 125132, 2011. https://doi.org/10.1093/mutage/geq052

FIORINO, E.; SEHONOVA, P.; PLHALOVA, L.; BLAHOVA, J.; SVOBODOVA, Z.; FAGGIO, C. Effects of glyphosate on early life stages: comparison between Cyprinus carpio and Danio rerio. Environmental Science and Pollution Research, v. 25, n. 9, p. 8542-8549, 2018. https://doi.org/10.1007/s11356-017-1141-5

FOLMAR, L. C.; SANDERS, H. O.; JULIN, A. M. Toxicity of the herbicide glyphosate and several of its formulations to fish and aquatic invertebrates. Archives of Environmental $\begin{array}{llllllll}\text { Contamination and Toxicology, } & \text { v. } & 8, & \text { n. } & 3, & \text { p. } & 269-278, & 1979 .\end{array}$ https://doi.org/10.1007/BF01056243

GAlli, A. J. B.; MONTEZUMA, M. C. Alguns aspectos da utilização do herbicida Glifosato na Agricultura. Santo André: ACADCOM Editora, 2005.

GLUSCZAK, L.; LORO, V. L.; PRETTO, A.; MORAES, B. S.; RAABE, A.; DUARTE, M. F. et al. Acute exposure to glyphosate herbicide affects oxidative parameters in Piava (Leporinus obtusidens). Archives of environmental contamination and toxicology, v. 61, n. 4, p. 624-630, 2011. https://doi.org/10.1007/s00244-011-9652-4

GREIM, H.; SALTMIRAS, D.; MOSTERT, V.; STRUPP, C. Evaluation of carcinogenic potential of the herbicide glyphosate, drawing on tumor incidence data from fourteen chronic/carcinogenicity rodent studies. Critical reviews in toxicology, v. 45, n. 3, p. 185208, 2015. https://doi.org/10.3109/10408444.2014.1003423 
HARAYASHIKI, C. A. Y.; VARELA JUNIOR, A. S.; SOUZA, A. A. M. De, COSTA, L. C. Da.; PRIMEL, E. G.; BIANCHINI, A.; CORCINI, C. D. Toxic effects of the herbicide Roundup in the guppy Poecilia vivipara acclimated to freshwater. Aquatic toxicology, v. 142, p. 176-184, 2013. https://doi.org/10.1016/j.aquatox.2013.08.006

KEGLEY, S. E.; HILL, B. R.; ORME, S.; CHOI, A. H. PAN Pesticide Database. Oakland: Pesticide Action Network, North America, 2016.

KIER, L. D.; KIRKLAND, D. J. Review of genotoxicity studies of glyphosate and glyphosatebased formulations. Critical reviews in toxicology, v. 43, n. 4, p. 283-315, 2013. https://doi.org/10.3109/10408444.2013.770820

LAGARDE, F.; BEAUSOLEIL, C.; BELCHER, S. M.; BELZUNCES, L. P.; EMOND, C.; GUERBET, M. et al. Non-monotonic dose-response relationships and endocrine disruptors: a qualitative method of assessment. Environmental Health, v. 14, n. 1, p. 13, 2015. https://doi.org/10.1186/1476-069X-14-13

LUSHCHAK, V.; KUBRAK, O. I.; STOREY, J. M.; STOREY, K. B.; LUSHCHAK, V. I. Low toxic herbicide Roundup induces mild oxidative stress in goldfish tissues. Chemosphere, v. 76, n. 7, p. 932-937, 2009. https://doi.org/10.1016/j.chemosphere.2009.04.045

MAÑAS, F.; PERALTA, L.; RAVIOLO, J.; OVANDO, H. G.; WEYERS, A.; UGNIA, L. e al. Genotoxicity of glyphosate assessed by the comet assay and cytogenetic tests. Environmental Toxicology and Pharmacology, v. 28, p. 37-41, 2009. https://doi.org/10.1016/j.etap.2009.02.001

MCMAHON, T.A.; ROMANSIC, J. M.; ROHR, J. R. Nonmonotonic and monotonic effects of pesticides on the pathogenic fungus Batrachochytrium dendrobatidis in culture and on tadpoles. Environmental science \& technology, v. 47, n. 14, p. 7958-7964, 2013. https://doi.org/10.1021/es401725s

MESNAGE, R.; DEFARGE, N.; DE VENDOMOIS, J.; SERALINI, G. E. Potential toxic effects of glyphosate and its commercial formulations below regulatory limits. Food and Chemical Toxicology, v. 84, p. 133-153, 2015. https://doi.org/10.1016/j.fct.2015.08.012

MESNAGE, R.; RENNEY, G.; SÉRALINI, G. E.; WARD, M.; ANTONIOU, M. N. Multiomics reveal non-alcoholic fatty liver disease in rats following chronic exposure to an ultra-low dose of Roundup herbicide. Scientific Reports, v. 9, n. 7, p. 39328, 2017. https://doi.org/10.1038/srep39328

MODESTO, K. A.; MARTINEZ, C. B. R. Roundup ${ }^{\circledR}$ causes oxidative stress in liver and inhibits acetylcholinesterase in muscle and brain of the fish Prochilodus lineatus. $\begin{array}{lllllll}\text { Chemosphere, } & \text { v. } & 78, & \text { n. } & 3, & \text { p. }\end{array}$ https://doi.org/10.1016/j.chemosphere.2009.10.047

NIMMO, D. R. Pesticides. In: Rand, G. M.: Petrocelli, S. R. (eds.). Fundamentals of Aquatic Toxicology: Methods and Applications. Princeton: FMC Corp., 1985.

POLETTA, G. L.; KLEINSORGE, E.; PAONESSA, A.; MUDRY, M. D.; LARRIERA, A.; SIROSKI, P. A. Genetic, enzymatic and developmental alterations observed in Caiman latirostris exposed in ovo to pesticide formulations and mixtures in an experiment simulating environmental exposure. Ecotoxicology and environmental safety, v. 74, n. 4, p. 852-859, 2011. https://doi.org/10.1016/j.ecoenv.2010.12.005 
RAND, G. M.; PETROCELLI, S. R. Fundamentals of aquatic toxicology: methods and applications. Washington: Hemisphere Publishing Corporation, 1985.

RELYEA, R. A. The impact of insecticides and herbicides on the biodiversity and productivity of aquatic communities. Ecological applications, v. 15, n. 2, p. 618-627, 2005. https://doi.org/10.1890/03-5342

SRINIVAS, U. S.; TAN, B. W.; VELLAYAPPAN, B. A.; JEYASEKHARAN, A. D. ROS and the DNA damage response in cancer. Redox Biology, v. 25, n. 2018, p. 101084, 2019.

STORRS, S. I.; KIESECKER, J. M. Survivorship patterns of larval amphibians exposed to low concentrations of atrazine. Environmental Health Perspectives, v. 112, n.0, p. 10541057, 2004. https://doi.or,g/10.1289/ehp.6821

TUREK, J. A.; GHISI, N. C.; MATOZO, S.; NOLETO, R. B. Efeitos citotóxicos de um herbicida à base de glifosato no peixe Astyanax altiparanae Garutti \& Britski, 2000. Luminária, v. 19, n. 2 p. 06-12, 2018.

WANG, D.; KREUTZER, D. A.; ESSIGMANN, J. M. Mutagenicity and repair of oxidative DNA damage: insights from studies using defined lesions. Mutation Research/Fundamental and Molecular Mechanisms of Mutagenesis, v. 400, n. 1-2, p. 99-115, 1998. https://doi.org/10.1016/S0027-5107(98)00066-9

WATT, N. T.; ROUTLEDGE, M. N.; WILD, C. P.; HOOPER, N. M. Cellular prion protein protects against reactive-oxygen-species-induced DNA damage. Free Radical Biology $\begin{array}{lllllll}\text { and Medicine, } & \text { v. 43, n. } & 6, & \text { p. } & 959-967, & \end{array}$ https://doi.org/10.1016/j.freeradbiomed.2007.06.004

WILLIAMS, G. M.; KROES, R.; MUNRO, I. C. Safety evaluation and risk assessment of the herbicide Roundup and its active ingredient, glyphosate, for humans. Regulatory

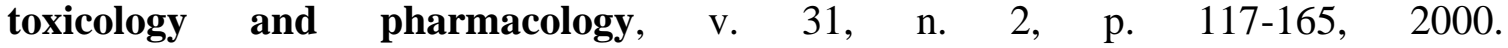
https://doi.org/10.1006/rtph.1999.1371 